\title{
Legal and contractual foundations of intellectual property of design of construction projects
}

\author{
Hossein Behsan $^{1 *}$, Vahid Shahhosseini ${ }^{2}$ \\ ${ }^{I}$ M.Sc., Civil Engineering Construction Management, Amirkabir University of Technology, Tehran, Iran \\ ${ }^{2}$ Assistant Professor, Amirkabir University of Technology, Tehran, Iran \\ *Corresponding author E-mail: hossein_behsan@hotmail.com
}

Copyright $\odot 2014$ Hossein Behsan, Vahid Shahhosseini. This is an open access article distributed under the Creative Commons Attribution License, which permits unrestricted use, distribution, and reproduction in any medium, provided the original work is properly cited.

\begin{abstract}
Viable improvement of any complex in micro and macro scales requires producing novel plans and having the complex to make use of innovative technologies and findings. In most developmental projects, the project consultants are responsible for producing plans and for directing the projects towards providing the opportunity to make use of the mentioned facilities. The beneficiaries' interests are considered as one of the issues to be considered while producing and directing plans. The interests of the projects' consultants include material and intellectual property of the plans made. Because some deficits exist in intellectual property law and the period of the legal proceedings is too long, it is possible that when the plan is made within the project consultancy group, other legal and real persons ignore the goals of the project and begin to use the plan just for the progress of their own interests. Emphasizing on the intellectual property of the plans made by the consultants, present regulations, comprehensiveness of the regulations and the necessity of ratification of the appropriate regulations, this essay deals with the intellectual property of the innovative plans.
\end{abstract}

Keywords: Intellectual Property - Consultant - Plans of Developmental Projects - Contracts

\section{Introduction}

One of the most important issue human minds focused and concentrated on it, is property. Regarding technological developments and the ease of communication between individuals, groups and organizations, the property of nonmaterial issues such as thinking, ideas, and their consequences are amongst the existing challenges [1].

Although the issue of intellectual property has been raised from long time ago and some acts has been developed and protected it, the deficit of the developed regulations, not being revised and amended up to now, and also non-existence of a specified appropriate law for today life in state in a manner that intellectuals and elites can publish their thoughts free from worries, have caused intellectuals be uncertain about providing their ideas publicly.

For discussion in this context, the history of intellectual property rights during a variety of periods of time, the prevailing ideas and opinions in a variety of periods according to the history, the developed acts and their evolutional processes, and also international treaties for property rights all should be investigated. Then a comparison between the present acts should be performed, their disadvantages and deficits especially in the field of designing and architecture should be distinguished, and some recommendations should be presented for amending them [1].

The history of intellectual property, the prevailing ideas and opinions during different periods of time

Lawyers, anthropologists and historians expressed different ideas about the existence or advent of intellectual rights in a variety periods of time. The following section presents some of the above ideas briefly [2].

\section{Ancient societies}

Andre' Morillot writes:" the intellectual property of the authors has existed from a long time ago when man could take brush and pen in his hand. The origin of this right had been lost in the darkness of times. As literature came to existence, 
piracy was blamed by people, and as some regulations and acts were developed, this piracy has been punished." Jean Vilbois in his turn believes that there always were some authors' intellectual rights within all societies.

Current anthropologists have found the works of creators' intellectual rights in primitive communities. Professor Dock writes:" we find a variety of intellectual property even in Negritos [2].

He has noted numerous evidences for Ancient Rome and Greece too, and he thinks as ancient Rome didn't feel that it is necessary to protect the creators of works, there were no legal text in this field; and at those times, as authors enjoyed a high social status and accorded reverence and received good material rewards, they tranquility were just concerned about their arts with all their beings. Therefore, they never thought about asking for their rights, with respect to obtaining material advantages, being rendered formal.

\section{Middle ages}

As the levels of cultures and literature and science improvements were the same during the period between fifth century to sixteenth century, creators' intellectual rights had undergone different changes during middle ages. Hence, a kind of decline has been seen everywhere in all fields from fifth century to twelfth century, while from twelfth century onwards, there were the consequences of progresses and prosperities in European universities. The main cause of the decline in intellectual works during approximately seven centuries is that not only the method of publications and the publication of works had not undergone any changes comparing ancient times but also because of the disorganization of the forces and collapse of the civilization in Rome Empire, and the destruction of open market for intellectual works due to the church dominance on them, seldom a work could be completed and specially could reach to publication stage. If a work is to be protected with respect to its author's intellectual rights, the society should believe that this work is the result of the thought and talents of its author. But in the beginning of the Middle Ages, people and specially the church believed that the work is a manifestation of divine inspiration, therefore its creator could not be entitled to possess exclusive rights over it. Hence most works were published anonymously, for the only task of the author was to be a means to present the divine inspiration. [3].

\section{New age (16th and 17th centuries)}

From the beginning of the $16^{\text {th }}$ century, the above mentioned bad conditions had undergone some changes due to the following reasons: [3].

\subsection{Invention of publication industry}

The publication industry has been prevailed from $16^{\text {th }}$ century onward. The publication industry per se was nothing but a technique for conveying thoughts and it can't be the origin of works unless through existence of intellectual works. What gives meaning to the publication industry is the thought, prevailing across the society through this industry. Renaissance brought these thoughts [4].

\subsection{Religion reform movement}

This movement apparently is not related to the subject of this paper, but in fact, it greatly has helped humanly personality, authors and artists' personalities to flourish and to receive credit.

\subsection{Renaissance}

The most important event in this century is a great intellectual movement, although it has been originated from $13^{\text {th }}$ century in Italy but it has manifested itself in $16^{\text {th }}$ century. This movement which has been called Renaissance, according to Eugenio Garin," primarily is born of a concept of life and reality, penetrated in art, literature, science, ethics and everywhere. [4]

For the subject of our discussion, historians believe that renaissance, on one hand, has led to honoring and revering human personality specially the personality of the authors, thus the authors are no more anonymous, as they were anonymous in Middle Ages; on the other hand, the art now is free from irreverence and discredit. The existing literature on Pis church by Giovanni Pisano, Italian sculptor and architect in $14^{\text {th }}$ century, is a sufficient proof for it.

It goes without saying that the authors' rights also enjoyed the same social changes and the honor and reverence accorded to writers and artists. From $16^{\text {th }}$ century onward, the society's theoretical and objective conditions has led to prosperity of thought leakages, and the creators of literary work and work of art are aware of their own value and credit . This awareness has made authors to be determined to vindicate their own rights. The consequences of these social and thinking changes have been appeared under an act ratified for protecting authors for the first time in United Kingdom. 


\section{Eighteenth and nineteenth centuries}

Anne act, 11th ratified 1709 By the $18^{\text {th }}$ century, thoughts, custom and tradition in European societies had undergone profound changes, the creators of literary works and works of art have been aware of their rights, they attempted to gain what they were entitled to own conventionally to own in reality under act too. From the beginning of the $11^{\text {th }}$ century, a memoir under the title of "Memoirs of Paris Publishers Offences" had been passed from hand to hand in France. This paper showed the ideas of authors about the publishers owned the sale of books exclusively. Five years later, in another memoire, Louis d'Hericourt, a lawyer and specialist in churches affairs, presented an independent idea about the authors rights which had been mixed with royal privileges and ignored in those times. This was due to claims raised by provincial publishers against Paris publishers. From the perspective of our discussion, what has made the core of Harry Cur reply is that the writer is definitely the owner of the work created by him; because the rights of the creator originate from the act of creating by mind rather than from obtaining a tangible object. [2]

Harry Cur writes:" a manuscript, containing nothing against religion, the state rules or public interests, is considered as a property owned by its creator so that as no one is entitled to deprive him of his money, fittings, or land owned through working, no one is entitled to deprive him of the said work. The creator needs to be free from limitations in order to be able to make decision, so that in addition to be proud of the work he created, he can gain some money through publication of the work for his own livelihood or for his family or his friends."

In 1709, the first act for protecting authors was ratified during the reign of Queen Anne. The title of this act is an Act for Encouragement of Learning. Two other important acts were also ratified in France by the parliament in 1791 and 1793 too. The first act is Loshaplie Act which is related to the right to display the work; and the second act is Lakanal Act related to the right of publication and reproduction. [3]

\subsection{The international law and intellectual property}

Undoubtedly, the protection of national law for intellectual property rights shall not be effective unless being protected by international contracts. Therefore, some efforts have been made globally in order to make this protection a public action.

The record of international efforts to protect intellectual property rights and to improve supervising regulations for protecting intellectual property rights over the previous century shows that these efforts were performed generally through the help and protections of World Intellectual Property Organization (WIPO) and the subordinated organizations. These efforts led to the ratification of some conventions and agreements, developing some international obligations for protection of the owners of the intellectual property rights. [1]

The conventions are of two kinds:

a) International Treaties for Industrial Ownership Rights.

b) International Treaties for Literary and art works' property rights.

The contradiction between the previous conventions and agreements and non-existence of an effective executive framework had led to the intellectual property rights being raised in Uruguay debates round in the form of "General Agreement Tariff and Trade", called GAT, and at last it led to the ratification of "Trade Aspects of Intellectual Property Rights Agreement" (TRIPS).

\subsection{Copyright and its secondary rights and their conceptions}

Under Common Law, the rights of the authors of the literary, music and art works are referred Copyright, and under Roman law they are referred Author's Rights. Generally, copyright is a right established for protecting literary, fictional, musical, art works and other works originated from the minds of the authors.

The term copyright generally is applied for the most important action performed for literary and art work; i.e. making copy from a work such as a book, painting, statue, illustration and film can be possible only if it is performed by the author or through obtaining permission from him.

But the term author's right is applied for the person created the literary or art work; i.e. the author himself. The right of author emphasizes that the author has special right in his work applicable just by himself; such as the right to prevent the reproduction of the distorted work. But other rights, such as the right to make a copy or the right to reproduce a work are transferrable and can be applied by other persons too; for example, the publisher acquire the right of reproduction from the author[5].

However, these rights are called Copyright in TRIPS Agreement. It's noteworthy that it is the method of the author to express his beliefs that is protected rather than the beliefs. Copyright actually protects innovation in choosing and organizing words, musical notes, colors, graphs, and so forth. In copyright, the method the author uses to present the original work is protected against unauthorized copying by others. To benefit from copyright protection, the work should be original. The term original refers to the work created by the author himself. Of course, the author is not required to present novel and innovative ideas; but the method he uses to present the ideas should be novel and innovative. Therefore, as the criterion for protection doesn't constitute innovation and novelty of the work but it constitutes the originality of it, the rights of the creator shall not prevent the creation of an independent similar work by 
others. It is noteworthy that the quality or the value of the work or even the aim and the objective of the author for creating it and the type of use to be made of the work are not related to the protection of it. Therefore, regardless of being considered good or bad, a literary work or a musical work shall be under protection. [5].

\subsection{The background of intellectual rights of the authors in Iran laws}

We consider two processes of "lack of laws principle" and "developing law" in order to investigate the background of the intellectual rights in Iran.

Returning to the lack of law principle, we face with a period of time during which no codified principle or criterion existed in Iran law, and when some bad actions performed, they were just treated and blamed as blameworthy actions. Therefore, the literary and art works property in current terms are not considered as phenomena which their tracks could be found in Iran. But, in the past, there were some cases such as some quotations of others' works without the source being mentioned, and also some people ascribed the works created by others to themselves. [3].

\subsection{The definition of intellectual property rights}

Intellectual Properties are defined as a variety of properties and definite dominance on intellectual works for the creator. From a legal point of view, the term intellectual property refers to rights and privileges for intellectual subjects.

In United States, intellectual property includes rights created through the right of copying, the right of registration the patent, and trademark rights.

Iran lawmaker has not defined intellectual rights; but regarding the different provisions of an act ratified on 1348 (1969) and making use of comparative law, intellectual rights can be defined as:" intellectual rights are legal, non-material advantages pertaining to the creator of an intellectual work so that by virtue of them the creator can benefit from a special kind of rights permanently. Due to this right, to study the author's right content begins. From a legal point of view, this right shows a relationship between the work and its creator. By this right, the creator shall benefit from the privileges never removed even after his death. The composition of work shall be assigned to the heirs or successors of the deceased author - under his name - through this right".

The intellectual rights are generally divided into two parts:

1) Industrial and Commercial Property Rights.

2) Copyright and Its Secondary Rights.

Industrial \& Commercial Property Rights Include patents, Trademarks \& Commercial Names, Passing Off, Industrial Designs, and Geographical Indication, Layout-Designs (Topographic) of Integrated Circuits, Undisclosed Information, Unfair Competition, and Industrial Design.

The author's rights contain a variety titles, divided into several subcategories: [4]

1) The written and unwritten literary and scientific works including books and papers.

2) Art works.

3) Ornamented and Dramatized works

4) Computing Works and Information Databases

From a lexical standpoint, copyright means copying or author right; but from a terminological standpoint it is the right of the creator of literary, scientific, art works. Copyright can include a wide range of works from written works to audiovisual works, visual works, art crafts, carpet and rug designs, and computer software. The correct meaning of copyright is the right of publication, rather than royalty or the fee of the author.

One of the debates in this regard is that to which of the said categories do the industrial designs belong? Replying this question, we need to make a distinction between the designs characteristics, because industrial designs can benefit from protection from two different aspects; if the artistic and aesthetic aspects of these designs are considered, these designs may be included in literary-art category and be protected under the law for protection of literary-art property, but if they are considered from industrial aspect, they are included in Industrial property category too [5].

This agreement which is related to the relevant aspects of the trade of intellectual property rights does not include a definition for industrial design. Vipoe presented a definition for industrial design in his site:" the industrial design constitutes the ornamental or aesthetic aspect of an article. An industrial design may consist of three-dimensional features, such as the shape or surfaces of an article, or of two-dimensional features, such as patterns, lines or colors [5]. The definition of industrial design in UK Law, one of the first laws for industrial design, is as follows:" a (an industrial) design constitutes the aspects of the shape, pattern, or ornaments used for an article, produced through an industrial process. These aspects should be significant and seen in the finished product. Techniques or methods for manufacturing the product and aspects of shape and structure related to the function of the product or related to the spare parts or complementary products shall not benefit from the protection under this law."

One of the most important issues in industrial design protection is that the protection is effective and applicable when the design is manifested in an article. In fact, the philosophy for industrial design protection implies that a design made an article attractive and led the customers to prefer using an article over another one, should be encouraged. Thus a design that is only on a paper and is not applicable in an industrial product shall not be considered as an industrial design; it is an art design and is included in literary-art property context. In fact, the reason for protection of industrial 
design in a context separated from protection of literary-art property context has been to provide special protection for the designs containing industrial predictability feature [5].

Another important and significant issue is a legal system arising from employment relationship. This implies a situation in which a designer employed by others in order to create a design. After a design made, a question is raised: who is the holder of design right, a hireling or a lessee; or in a new term: who is the right holder, an employer or an employee? Before addressing above issue, it should be noted that the design right legal system originating from employment relationship has basically been different in Common law and Roman law countries. In employment contracts, the employer is considered as the holder of design material rights under common law, but under Roman law, the creator is considered as the right holder. Nevertheless, the fact is that the difference in recognition of the holder of design rights is due to the method of interpretation of the details of the design right. Analyzing the details, it has been cleared that the differences are not the same as they have been seen at the first glance. Two kinds of rights are recognized within the context of the industrial design: Material Right and Intellectual Right. The material rights of the design are depended upon the personality of the creator of the design, thus the creator owns the rights; but the material rights are transferrable. In common law countries, the employer shall be considered as the holder of the material rights of the design from the initial process of creating the design by its creator, but in Roman law countries these rights shall belong to the employee and the employee shall designate the rights to the employer through concluding a contract. This division is followed by legal consequences, so that if the employee refrains from delivering the design to the employer, regarding that one of the intellectual rights of the creator is the option to disclose information, he can maintain the design and to compensate the damages incurred by him. But in employment relationship in common law countries, the designer shall not be entitled to refrain from delivering the design to the employer, because the design shall belong to the employer, and if he refrains from delivering it, the employer can force him to deliver it through filing a claim against him. This system acts in favor of the employer; While Roman law system acts in favor of the creator of the design [6].

It seems that common law system has acted more reasonably than the Roman law system, and even saying that Roman law has acted mostly in favor of the creator is wrong. If the investor is not sure that in addition to the money he invests, he gain some profit too, he is discouraged from investing in this field, because there is no guarantee that the designer delivers the design he made through using the money invested by the employer, and even if the designer compensates the damages he incurred, the employer can't gain the interests he expected to gain through this work. Therefore, Roman law system is neither in favor of the creator nor in favor of the investor. In our country, a design made by an employee who has been employed to create it contractually shall belong to the employer. Of course, a condition can be included in the contract contrary to the above case, and this contrary condition shall be valid.

One of the significant issues in legal system is design right for collaborative works. A collaborative work is made through the collaboration of different people. The collaborations performed to make the work, are related to each other through a common goal and common ideas.

The general principle in law in different countries such as France, Germany, Aljazeera, Belgium, Egypt, Brazil, Chile, Italy, and Iraq is that the collaborative work shall belong to the authors' common property, and their rights are enforced commonly; while in other countries such as El Salvador, Mexico, and Portugal, the majority permission is suffice to enforce the common rights of the creators of the collaborative work. In most countries, if there is no majority or consensus, the legal court makes the final decision [6].

Another significant issue in legal system is about on-demand-work. An on-demand-work is a work created by designer upon receiving an order. As for the works originated from employment, in common law countries, the rights of ondemand-works shall belong to the person places the order, while in Roman law countries, the said rights shall belong to the creator of the work [6].

\subsection{Intellectual property rights in Iran}

According to the law of Islamic Republic of Iran, the person who creates a work through using knowledge, art and/or innovation is called "the creator", and what is created through activity, innovation and initiative of the creator is called "work". A work created through cooperation and collaboration between two or more creators, in a way that their works can't be distinguished as distinct works, is called "collaborative work". According to Iran law, regardless of the method and style used for creation of the work, the rights of the creator, who involved in creating the work, shall be under the protection of the law.

But one important issue is that the law doesn't protect all works definitely, and a work shall benefit from law protection that: firstly it is or has been published, broadcasted or performed for the first time in Iran, and none of the mentioned activities had already been performed in other countries; and secondly the nature of the work clearly is specified in law.

\subsection{The nature of the intellectual property rights from the law knowledge standpoint}

The lawyers have different points of view. The most important amongst them are as follows:

1) Natural Rights Viewpoint. 
In the beginning of $18^{\text {th }}$ century, a question of whether the author's right is considered as a part of natural rights in common law context or it is designated to others under the order of the king or special regulations had been raised. The most important point of view was that the author's right is an intrinsic right and it is a kind of property. Now, there are some individuals supporting this view. F. Heppe, the former head of the UNESCO Administration of Authors' Rights believes that the author's right, existed from a long time ago, constitutes the natural or intrinsic rights, and in the course of time, human became aware of it.

2) Labor rights viewpoint.

A number of authors of civil rights such as Platiul and Riper believe that the author's rights and other intellectual property rights arise from the work of the holders, and these rights follow the Labor Rights. In their opinion, the same privileges considered under law for employee, are considered for the holder of intellectual right too, i.e. fee. Some persons such as H. Deboise, a French lawyer, believe that the bond between the literary and art works and their creators are out of the scope of the labor rights, because the employee is entitled to receive a fee which is material rather than intellectual. Although Eugen Ulmer, a German lawyer, prefer revering the personality of the creator of intellectual work over royalty or material fee, some persons such as French Riper and Planiul consider the fee viewpoint as a foundation for the nature of the intellectual rights.

3) Personal rights viewpoint

A number of lawyers maintain that the creator right is a personal right, aiming only to protect and preserve the right of the person created the intellectual art work, and it can't be considered as a property of the creator; and it shall not be transferrable, transactional and inheritable.

4) Ethical viewpoint.

Others have considered the rights of intellectual art works as ethical rights, declaring that the aim of ethical rights is to protect the reverence of human personality and to honor it. As all these kinds of rights aim to honor the human personality and they are not limited to intellectual property rights, this viewpoint is not acceptable.

The creator rights are clearly specified by legislator in article 3 of the act for the authors, writers and artists' rights protection, ratified on January 1, 1970. This act only recognizes the intellectual rights but it doesn't provide any definition for it. This act has considered and protected three senses for intellectual rights of the creators.

According to article 17, the special name, title and indicator of the work are protected by this act.

It is resolved in article 18 that:" the assignee and the publisher and those who are authorized to make use of the documents or adoption of a work in order to acquire some profit, are required to acknowledge the name of the creator together with the title and especial indicator of the work, accompanying with the work or to insert them on the cover of the original work or the printed or reproduced editions as is customary; unless otherwise agreed by the creator."

It is resolved in article 19 that:" application of any changes or alterations in the works protected by the act and their publication without approval of the creator shall be prohibited".

Moreover, the articles 23 and 24 of the act for authors' rights protection specify that any infringement of the intellectual rights of the creators of the works shall deserve punishment.

It follows that Iran's law recognizes the right of publication, the parent right of the work, and the reverence right of the work, all of them are parts of the intellectual rights of the creators; but it has not spoken explicitly about the withdrawal right or restitution right, existing in some European countries laws.

A comparison made between the act for the authors, writers and artists' rights protection (ratified on January 1, 1970) hereinafter referred to as act, and the bill for protection of literary and art works' property rights and the pertaining rights, hereinafter called bill, and the investigation performed on their probable deficit regarding design works and architecture

In the law in question and the presented bill, refer to a number of works protected by the act. Paragraphs pertaining to design works and architecture are as follows:

According to the paragraph 5 in article 2 of the act, painting, illustration, design, pattern, geographical maps, manuscripts and ornamental graphs, and any ornamental work and visual work created using any method and technique, in any form, simple or mixes, all are protected. Paragraphs 8 to 10 of the bill also refer to the same.

One significant issue in this paragraph is related to design and pattern and ornamental graphs. Most of the traditional architectures especially religious constructed works in our country include special religious and traditional patterns, being repeated in most architectural designs. It seems that the above mentioned designs belong to the tradition and culture of the society and they can't be protected with respect to copyright, even though invention of a novel design.

Paragraph 27 of article 2, concerning the work protection, limits the architectural work to the design and drawing and map of the building. Paragraph 13 of the bill 1 considers an architectural work as a constructional design embodied in a form of a model or a building map.

A definition provided in United States copyright circular for architectural works are the same as the definition presented in the bill. Apparently, both of the above definitions are imperfect. Because it is possible a constructional set contains only one structure or one part of a structure that can potentially benefit from copyright. And also it is possible that, contrary to the property rights, a special building or a special part of a building are copied illegally and on the other hand, at first glance it seems that the design and architecture of the building are like other buildings. In this case, according to the of the bill, those parts shall not be protected from a legal point of view. 
According to article 19:" application of any changes or alterations in the works protected by the act and their publications without approval of the creator shall be prohibited". Regarding paragraph 7 of article 2 of the act for protected works, it can be concluded that changes or alterations shall not constitute the constructed architectural works. Therefore, applying a small change in a structure or a part of a structure, the offender might have reconstructed the work and by exploiting this gap, he may register the design in the name of his own.

Paragraph B of article 20 of the bill defines the reverence right of the work as a right by virtue of which any interference and possession in the content, form, title, or special indicator of the work are subject to obtaining the author's approval. At first it seems that this definition removes the gap mentioned in previous paragraph. But due to the incomplete definitions for architectural work in paragraph 13 of article 1, the legal question remains unsolved as the definition referred to in the previous paragraph.

Chapter four in the act and chapter two in the bill both contain some paragraphs about infringements and punishments for offenders. Due to a variety of potential infringements and the differences of loss incurred to the right holders, it is not reasonable to predict potential infringements and to determine compensations for each one.

Another obscurity in the act and the bill is related to the application of changes in the works protected; if a person, after performing some investigation and research and working on one of the protected works, can present a design similar to or better than the primary design, the court can't make a decision in this regard; as the court is not able to determine whether this work is a new idea or the old work and it is now regarded as a design infringing the rights.

It is resolved in the article 22 that:" for architectural works, legal users are authorized to apply changes in the work including reconstruction or repair without the approval of the creator, provided that technical considerations or the nature of usage necessitate the same."

This article produces a legal gap for those infringe the rights. Before the execution of the major developmental and architectural projects, the basic studies are performed by executive bodies and their consultants. These studies are performed on the basis of primary definition of the project performance. Meanwhile, technical considerations related to the project are determined for a project's elements perform correctly and ideally. Since copyright belongs to special and unique projects, and in these projects all goals and details are specified and explained, application of changes including renovation or repairs are not considered significant.

Article 55 of the bill addressing the works originating from orders or employment is explained reasonably. According to this article, intellectual rights in the works originating from order or employment belong to real persons creating the works. This paragraph is inconsistent with a number of the agreements and equivalent general conditions for contracts. A number of these inconsistencies are as follows:

1) According to the provisions of article 34 of the agreement and equivalent general conditions for consultancy services contracts (type 1), all documents and reports contractually provided by a consultant engineer including original works, transparent or computerized, belong to the employer. The consultant engineer can retain a reproducible copy of the documents and the reports. The consultant engineers, through performing studies, are authorized to present and publish the scientific articles in seminars, meetings and technical and scientific publications in the name of themselves in case no limitation included in particular conditions of the contract.

2) Article 30 of the agreement and equivalent general conditions for consultancy services contracts (publication No. 3419) are similar to article 34 of the agreement and equivalent general conditions for consultancy services contracts.

3) Article 56 of circular number 105/735-54/201 dated 17/04/2001 subject of the agreement and equivalent general conditions of the design management services contract (publication no 24121) are also similar to the article 34 of the agreement and equivalent general conditions for consultancy services contracts.

Article 33 of the bill which is about the reproduction of a work published without the permission of the right holder, has a drawback. Because a person may reproduce a work not for earning profits or money and then, the work may produce some profits for him. In this case, the probability of the drawback be followed up is low. It is noteworthy that the provisions of this article do not cover architectural works and it refers to them only in order to express the legal gap.

\section{Recommendations}

- Consider a separate paragraph for design, pattern, and graph especially for traditional and religious design, so that the material rights of the creators are paid and the ownership of the design is immediately designated to government or relevant ministry.

- Amend the definition for architectural work provided in the bill. I recommend that: an architectural work constitutes producing a design, a plan in a manner that the execution of a structure on the basis of it becomes possible. And also, a design, a pattern or a plan originated from applying changes in another design or plan is considered as a novel work in case that a specialist doesn't consider it as a similar plan to a primary plan.

- Define a special standard for distinguishing interference and possession in a bill submitted. For example, a comment provided by an impartial experimental expert can be a basis for making decision; so that if the impartial expert distinguishes the interference and possession in the plan through reviewing the case, court also confirms it.

- Develop the act so that upon the infringement of rights, regarding the effects of it on complainant(s), a punishment can be applied. 
- Eliminate the article 22 of the bill or to amend it as follows:" for architectural work, applying any changes in the work including renovation or repair, without the approval of the creator shall be authorized provided that the changes do not lead to changing the unexecuted architectural elements and details."

- Amend the provisions for articles with subject of documents ownership in agreements and equivalent general conditions of contracts so that intellectual property and material property related to the documents are separated and distinguished; in which case, the material property related to the documents and instruments shall belong to the employee and the intellectual property shall belong to the consultant.

- $\quad$ Regarding the general and particular definitions, develop a comprehensive and complete by-law for design works, architecture and the services related to consultants

- The above act should be developed in a manner that the interest for producing novel designs both in the context of the industry - leading to the growth of economy - and in the context of art - leading to the improvement and growth in art and a corresponding increase in state's revenues acquired from the increased exports and tourists attraction - increases.

- And also the act should be developed in a manner that the separation and distinction between architectural designs and developmental designs shall be possible. The act should specify how a design is determined as an industrial design or a literary-art design and which regulations protect the designs and which parts of the design are under the protection of which regulations.

- A special court for examination of and hearing the intellectual property issues should be convened and it should examine, solve and settle the problems and disputes immediately.

- Develop a separate act for design and architectural works, because neither the act developed in 1970 nor the presented bill refers to them.

\section{References}

[1] Zhang Yang, The Study on Law Disputes in Construction Project Contract Relationship, Physics Procedia, Volume 33, 2012, Pages 19992004, 2012 International Conference on Medical Physics and Biomedical Engineering (ICMPBE2012) http://dx.doi.org/10.1016/j.phpro.2012.05.314.

[2] Fani Antoniou, Georgios N. Aretoulis, Complexity in the Evaluation of Contract Types Employed for the Construction of Highway Projects, Procedia - Social and Behavioral Sciences, Volume 74, 29 March 2013, Pages 448-458 http://dx.doi.org/10.1016/j.sbspro.2013.03.048.

[3] Ulrika Badenfelt, Fixing the contract after the contract is fixed: A study of incomplete contracts in IT and construction projects, International Journal of Project Management, Volume 29, Issue 5, July 2011, Pages 568-576 http://dx.doi.org/10.1016/j.ijproman.2010.04.003.

[4] Sander Lenferink, Taede Tillema, towards sustainable infrastructure development through integrated contracts: Experiences with inclusiveness in Dutch infrastructure projects, International Journal of Project Management, Volume 31, Issue 4, May 2013, Pages 615-627 http://dx.doi.org/10.1016/j.ijproman.2012.09.014.

[5] Fani Antoniou, Georgios N. Aretoulis, Selection Criteria Used for the Choice of Contract Type for Major Highway Construction Projects, Procedia - Social and Behavioral Sciences Volume 48, 2012, Pages 3508-3517, Transport Research Arena 2012 http://dx.doi.org/10.1016/j.sbspro.2012.06.1314.

[6] Sergios Lambropoulos, Objective Construction Contract Award using Cost, Time and Durability Utility, Procedia - Social and Behavioral Sciences, Volume 74, 29 March 2013, Pages 123-133 http://dx.doi.org/10.1016/j.sbspro.2013.03.052. 